\title{
Cilliers Breytenbach The Historical Example in 1 Clement
}

\begin{abstract}
While previous research emphasised deliberative rhetoric employed by 1 Clement (van Unnik; Bakke), the current paper offers continued investigation on the function of historical examples as part of its argumentative strategy. The author of 1 Clement addresses the congregation in Corinth with an appeal to let concord and peace be the foundation of their community life, instead of strife and dissension. Illustrative parallels for 1 Clement can be found in contemporary writings by Dio Chrysostom, Aelius Aristides and Plutarch. They argue likewise in favour of concord by giving positive and negative examples from the past that reveal its benefit for household, polis or nation. 1 Clement adapts this widespread rhetoric strategy to expose the devastating role of jealousy for the Corinthian community, both for brotherhood and leadership. In addition, it promotes repentance and righteousness as positive values. Examples from the Greek Bible and from contemporary Christianity are thus fitted into Greek rhetorical tradition to form paradigmatic narratives for fellow Christians. 1 Clement therefore reveals a mode of reference to biblical tradition that is highly influenced by contemporary culture.
\end{abstract}

Cilliers Breytenbach: Theologische Fakultät, Humboldt-Universität zu Berlin/Department of Ancient Languages, Stellenbosch University, e-Mail: cilliers.breytenbach@cms.hu-berlin.de

One might almost say, therefore, that my speeches have had much the same fate as the pottery of Tenedos; for while all who sail that way put on board pottery from there, yet no one finds it easy to get it across in sound condition;

but many crack or smash it, and ere they are aware they have naught but sherds.

Dio Chrysostom, Oratio 42,5 (trans. H. Lamar Crosby)

This paper recaps on the title of a collection of essays edited by Laurence Welborn and myself in 2004: Encounters with Hellenism. ${ }^{1}$ In that volume we republished classical essays on 1 Clement by Adolf von Harnack, Werner Jaeger and Willem van Unnik. Harnack, Jaeger and van Unnik, coming from different disciplines, all realised that 1 Clement provides an excellent example of how early Christian

1 Cilliers Breytenbach and Laurence L. Welborn, eds., Encounters with Hellenism: Studies on the First Letter of Clement (Arbeiten zur Geschichte des antiken Judentums und des Urchristentums 53; Leiden: Brill, 2004). 
literature encountered Greek literary and philosophical tradition. Harnack justly regarded the use of the biblical examples and those from recent Christian history in 1 Clement 3-6 as part of ancient rhetorical tradition. ${ }^{2}$ Jaeger said that "like a second Demosthenes" the author divides his examples on the tragic effects of party strife and disobedience "into examples drawn from the remote past and others from more recent times known to his readers." ${ }^{3}$ Van Unnik's most important contribution to research on 1 Clement was his long essay on the literary genre of the letter presented to the Royal Dutch Academy of Sciences in $1970 .{ }^{4}$ Following a suggestion by Harnack and Jaeger, van Unnik argued convincingly that the letter belongs to deliberative rhetoric, having its closest parallels in the speeches of Dio Chrysostom and Aelius Aristides. Together with Odd M. Bakke's “Concord and Peace," "which gives a rhetorical analysis of the letter, van Unnik's research entered mainstream research on 1 Clement.

Adding evidence to support the hypothesis of van Unnik and Bakke that 1 Clement's strategies of argument can be best described with reference to deliberative rhetoric, I will argue that in advising the congregation in Corinth to leave strife and dissension and to return to concord and peace, the author made use

2 Adolf von Harnack, "Das Schreiben der römischen Kirche an die korinthische aus der Zeit Domitians (1. Clemensbrief)" (1929), in Breytenbach and Welborn, Encounters with Hellenism (see note 1), (1-103) 67.

3 Werner Jaeger, "Early Christianity and the Greek Paideia: 1 Clement" (1961), in Breytenbach and Welborn, Encounters with Hellenism (see note 1), (104-114) 104.

4 Willem C. van Unnik, "Studies on the So-Called First Epistle of Clement: The Literary Genre" (1970), in Breytenbach and Welborn, Encounters with Hellenism (see note 1), 115-181. Unfortunately van Unnik's original study was in Dutch and several authors who studied the education of the author of the letter failed to consult it (e.g. Peter Lampe, Die stadtrömischen Christen in den ersten beiden Jahrhunderten: Untersuchungen zur Sozialgeschichte [WUNT II 18; Tübingen: Mohr Siebeck, 1987, 2d ed. 1989]; trans. Michael Steinhauser, From Paul to Valentinus: Christians at Rome in the First Two Centuries [London: T\&T Clark, 2003]). The German commentators on 1 Clement, Andreas Lindemann (Die Clemensbriefe [Handbuch zum Neuen Testament 17; Tübingen: Mohr Siebeck, 1992]) and Horacio E. Lona (Der erste Clemensbrief [Kommentar zu den Apostolischen Vätern 2; Göttingen: Vandenhoeck \& Ruprecht, 1998]), disagree with van Unnik that the letter can be classified as deliberative rhetoric and maintain that it is a real letter. More specifically, Lindemann, Clemensbriefe (see above), 12-13, suggests that 1 Clement can be understood as an énteuksis ("petition"/“entreaty"), cf. 1 Clement 63,2 (SUC 1, 104,22 Fischer). The Roman congregation intervenes with the supplication in the conflict in Corinth and argues in favour of the restoration of concord and peace in the congregation. Lona, Clemensbrief (see above), 21-22, wants it to be understood within the parameters of communication through letter writing and reading. 5 Odd M. Bakke, “Concord and Peace”: A Rhetorical Analysis of the First Letter of Clement with an Emphasis on the Language of Unity and Sedition (WUNT II 143; Tübingen: Mohr Siebeck, 2001). 
of the historical example. ${ }^{6}$ This path has been taken in a rather brief section by Bakke, ${ }^{7}$ who rightly states that "the very essence in deliberate proof by examples is that the examples function as an implicit, and in many cases as an explicit, appeal to the audience to imitate the positive and to avoid the negative." ${ }^{8}$ Bakke, though, confines his examples to Isocrates. Drawing on authors contemporary to the writing of 1 Clement, I will argue that the unknown author's strategy fitted into contemporary practice of deliberative rhetoric.

In his Rhetorica, Aristotle reminds us that persuasion is brought about, either

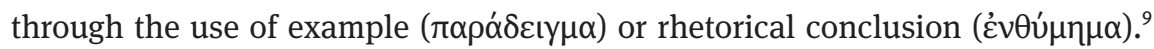
The example is based on induction. Aristotle explains in his Topica that "induction is a passage from individuals to universals, e.g. the argument that supposing the skilled pilot is the most effective, and likewise the skilled charioteer, then in general the skilled man is the best at his particular task." ${ }^{10}$ In all instructions,

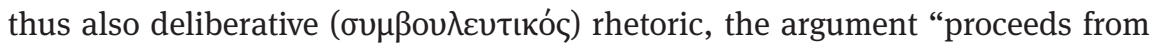

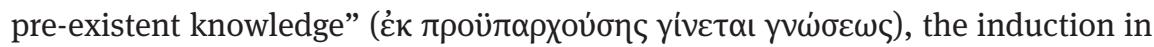
particular is making use of old knowledge to impart new knowledge, exhibiting the universal as implicit in the clearly known particular. ${ }^{11}$ On the basis of similarity it is assumed that future things will be like those of the past. The historical example in deliberative rhetoric thus relates things that have happened before, making use of the known individual cases to induce a general principle that can be used to give advice in an analogous case. ${ }^{12}$

6 According to Aristotle, advice in deliberative rhetoric is given to help men to attain happiness

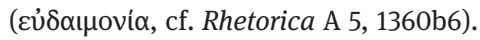

7 Bakke, "Concord and Peace" (see note 5), 60-61.

8 Bakke, "Concord and Peace" (see note 5), 56.

9 Aristotle, Rhetorica A 2, 1356b5.

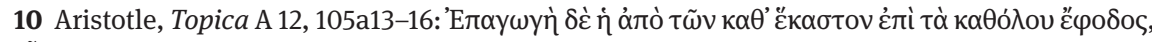

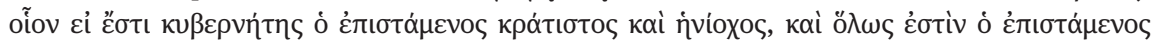

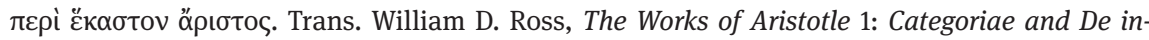
terpretatione, Analytica priora, Analytica posteriora, Topica and De Sophisticis elenchis (Oxford: Clarendon Press, 1928; repr. 1955).

11 Cf. Aristotle, Analytica posteriora A 1, 71a1-2.

12 Cf. Aristotle, Rhetorica A 9, 1368a, A 2, 1357b and B 20, 1393a. For a fuller review of the development of theory on the historical example, cf. Karl Alewell, Über das rhetorische ПАРААЕIГMA: Theorie, Beispielsammlungen, Verwendung in der römischen Literatur der Kaiserzeit (Leipzig: Hoffmann, 1913); Kristoffel Demoen, "A Paradigm for the Analysis of Paradigms: The Rhetorical Exemplum in Ancient and Imperial Greek Theory,” Rhetorica 15 (1997): 125-158; Daniela Dueck, Strabo of Amasia: A Greek Man of Letters in Augustan Rome (London: Routledge, 2000). 
The historical example was used extensively in Greek rhetorical tradition, losing none of its importance in Roman times. ${ }^{13}$ In order to have a backdrop to analyse some of the examples in 1 Clement, let me have a brief look at the use of the historical example in the Bithynian Orations of Dio Chrysostom, ${ }^{14}$ in the discourses on concord by Aelius Aristides and in some works of Plutarch. ${ }^{15}$

Drawing his discourse to the Nicomedians on concord to a close, Dio Chrysostom underlines the benefits of the advocated concord with the Niceans. It illuminates those things causing pain, like "envy and rivalry and the strife, which is their outcome." ${ }^{16}$ Of the examples Dio uses to illustrate concord, like the bees working together, the agreement between skipper and crew, charioteer and horses, ${ }^{17}$ the author of 1 Clement shares those about concord in the household and in the polis and the harmony within the cosmos. ${ }^{18}$

Addressing his home city, Prusa, Dio says that it is his habit to employ illustrations from Greek history. ${ }^{19}$ He uses Epaminondas of Thebes's way of dealing with a harsh opponent in his own Theban dialect as an example why he himself can speak frankly to his native Prusians. ${ }^{20}$ He has to deal with incompetent and envious men. ${ }^{21}$ Epaminondas in comparison "was hated by those who were not like

13 For a survey on this, cf. Frederick E. Brenk, "Setting a Good Exemplum: Case Studies in the Moralia, the Lives as Case Studies," in idem, With Unperfumed Voice: Studies in Plutarch, in Greek Literature, Religion and Philosophy, and in the New Testament Background (Potsdamer Altertumswissenschaftliche Beiträge 21; Stuttgart: Steiner, 2007), (195-215) 201.

14 I have selected these discourses because their overlap in terminology with 1 Clement is extensive. On the Bithynian Discourse, cf. Marcel Cuvigny, Dion de Pruse: Discours Bithyniens (Discours 38-51) (Centre de Recherches d'Histoire Ancienne 129; Paris: Les Belles Lettres, 1994); Christopher P. Jones, The Roman World of Dio Chrysostom (Loeb classical monographs; Cambridge: Harvard University Press, 1978), 83-94, 101-102.

15 For an analysis of exempla in Senecas De ira, cf. Brenk, “Good Exemplum” (see note 13), 204-206. 16 Dio Chrysostom, Oratio 38,43 (ed. Hans von Arnim, Dionis Prusaensis quem vocant Chrys-

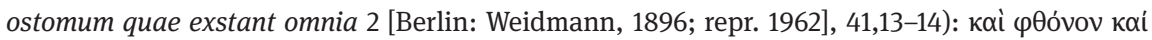

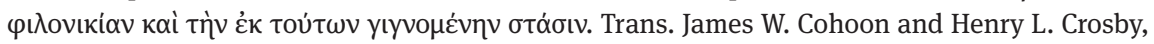
Dio Chrysostom 4 (Loeb Classical Library 376; London: Heinemann, 1946; repr. 1986), 87.

17 E.g. Dio Chrysostom, Oratio 38,14-15 (2, 33,12-34,1 A.); 39,6 (2, 45,10-19 A.); 40,40-41 (2, 57,3-18 A.).

18 On this, cf. Bakke, "Concord and Peace" (see note 5); Cilliers Breytenbach, "Civic Concord and Cosmic Harmony: Sources of Metaphoric Mapping in 1 Clement 20:3," in idem, Grace, Reconciliation, Concord: The Death of Christ in Graeco-Roman Metaphors (Supplements to Novum Testamentum 135; Leiden: Brill, 2010), 297-311.

19 Cf. Dio Chrysostom, Oratio 43,3 (2, 63,19-23 A.); cf. also 50,2 (2, 98,10-18 A.).

20 Cf. Dio Chrysostom, Oratio 43,4-6 (2, 63,25-65,4 A.).

21 Cf. Dio Chrysostom, Oratio 43,1 (2, 63,7 A.). 
him." ${ }^{22}$ Some slandered him, misleading the common people. ${ }^{23}$ Dio is innocently accused by slanderers and demands to be heard before being condemned as was the case with Socrates in Athens. ${ }^{24}$ Like Odysseus, whose home was taken, wine was drunk and cattle killed during his absence, Dio, during his long absence

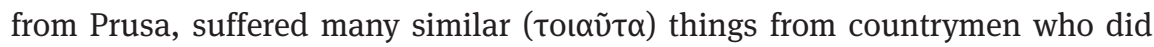
not expect him to return. ${ }^{25}$

Nevertheless, Dio means it well with his patria. Like Zeno, Chrysippus and Cleanthes who abandoned their own countries and chose to dwell amongst other people, ${ }^{26}$ he still subscribes to the doctrine that a philosopher should take part in the public affairs of his native city. He knows that, for a philosopher, life is hard at home: Heracles was mistreated by the Thebans, Homer spent all his time abroad, "stateless," and Pythagoras was honoured, but not in Samos. ${ }^{27}$ Why does Dio compare ( $\pi \alpha \rho \alpha \beta \alpha \dot{\lambda} \lambda \omega$ ) himself with these men? In the light of his experience in Prusa, he shares the opinion of those philosophers that life in their own native land was hard. Even if he sojourned abroad, he loves his patria, as did Homer. Philosophers staying home do not necessarily benefit the fatherland, as can be seen in the case of the Athenians whose conduct caused the death of Socrates. ${ }^{28}$

Addressing the council in Prusa, Dio states that a true philosopher learns how to rule well and can give counsel to men in power. ${ }^{29}$ Agamemnon sought the advice from Nestor, Alexander from Aristotle, Philip of Macedonia from Pelopidas and Epaminondas. ${ }^{30}$ Philosophers did not rule, but the Athenians benefitted from Solon, Aristides and Pericles, the Thebans from Epaminondas, the Romans from Numa, the latter influenced by the Pythagoreans. ${ }^{31}$ By analogy, Dio implied that it would be wise to let him take office, but in Prusa someone else had been

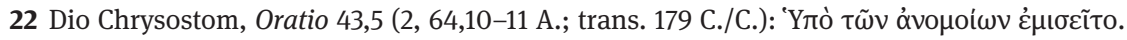
23 Cf. Dio Chrysostom, Oratio 43,5 (2, 64,11-22 A.).

24 Cf. Dio Chrysostom, Oratio 43,12 (2, 66,28-29 A.).

25 Dio Chrysostom, Oratio 45,11 (2, 74,25-26 A.). On Dio's appeal to authority by citing or alluding to Homer: Oratio 11,147 (ed. Hans von Arnim, Dionis Prusaensis quem vocant Chrysostomum quae exstant omnia 1 [Berlin: Weidmann, 1893; repr. 1962], 152,28-29); 12,22 (1, 160,24-29 A.); 44,1 (2, 67,6-7 A.); 80,7-8 (2, 224,9-225,5 A.); or to Euripides: Oratio 23,2 (2, 273,23 A.); 51,1 (2, 101,19-20 A.), cf. Anne Gangloff, Dion Chrysostome et les mythes: Hellénisme, communication et philosophie (Collection Horos; Grenoble: J. Millon, 2006).

26 Cf. Dio Chrysostom, Oratio 47,2 (2, 81,6-8 A.).

27 Cf. Dio Chrysostom, Oratio 47,4-6 (2, 81,14-82,13 A.).

28 Cf. Dio Chrysostom, Oratio 47,7 (2, 82,15-19 A.).

29 Cf. Dio Chrysostom, Oratio 49,3 (2, 94,5-15 A.).

30 Cf. Dio Chrysostom, Oratio 49,4-5 (2, 94,15-95,5 A.).

31 Cf. Dio Chrysostom, Oratio 49,6 (2, 95,5-14 A.). 
elected for office. ${ }^{32}$ Turning to negative examples, Dio states that this person had been entrusted with education, has supreme authority over temperance, order and the right conduct of everyone. Dio is critical of this and illustrates that never before men had bestowed such honours upon a fellow citizen. In Athens, not even Pericles held all offices all the time. ${ }^{33}$ What has happened in Prusa recently is not in analogy with what happened in the past and therefore not advisable.

In his symbouleutic speech “Concerning Concord” (Oratio 23), Aelius Aristides urged the cities of Asia to stop their rivalries (163 C.E.). In Oratio 24, he appeals to the Rhodians to refrain from internal strife. Aelius, not unlike Dio, ${ }^{34}$ underscores the importance of concord for the household and the city ${ }^{35}$ and refers to Homer, ${ }^{36}$ Hesiod,,$^{37}$ and Solon ${ }^{38}$ in support of his argument. In Oratio 23, he states that "everywhere faction is a terrible, disruptive thing." 39 "Faction is not only the cause of envy, but also of fear, crime, folly, and in sum of every evil." ${ }^{40}$ It is thus not wise or fortunate when the Greeks have strife amongst themselves. Aelius backs up his opinion with examples from the past. Whilst the Spartans and the Athenians shared the same goals and perspective, together they defeated the Persians, their power being envied by all the Greeks. This concord led to the leadership of the Athenians. But when the Athenians and Spartans engaged in fights over leadership, it ended in the mutual slaughter of the Greeks and the rise of Thebe. ${ }^{41}$ Since Athens, Sparta, and Thebes did nothing in common and with reason, the Phocian wars and Thermopylae followed. In the end, Philip of Macedonia ruled the Greeks. ${ }^{42}$ For Aelius, this all was due to the lack of concord. The difference between concord and strife is no small matter. ${ }^{43}$ He used the examples to illustrate

32 Cf. Dio Chrysostom, Oratio 50,6 (2, 99,18-27 A.).

33 Cf. Dio Chrysostom, Oratio 51,7 (2, 103,14-21 A.).

34 Cf. Dio Chrysostom, Oratio 38,15 (2, 33,2-34,2 A.).

35 Cf. Aelius Aristides, Oratio 24,7-8 (ed. Bruno Keil, Aelii Aristidis Smyrnaei quae supersunt omnia 2: Orationes XVII-LIII continens [Berlin: Weidmann, 1958], 56,21-57,20).

36 Cf. Aelius Aristides, Oratio 24,7 (57,2 K.).

37 Cf. Aelius Aristides, Oratio 24,13 (58,23 K.).

38 Cf. Aelius Aristides, Oratio 24,14 (59,9 K.).

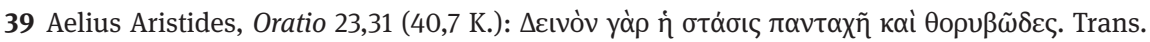
Charles A. Behr, P. Aelius Aristides: The Complete Works 2: Orations XVII-LIII (Leiden: Brill, 1981), 32.

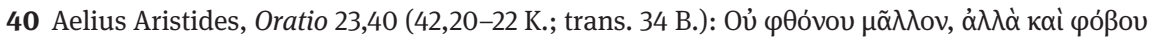

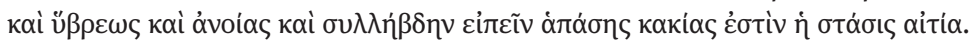

41 Cf. Aelius Aristides, Oratio 23,42-50 (43,2-45,26 K.).

42 This argument is repeated in Aelius Aristides, Oratio 24,24-27 (62,1-24 K.).

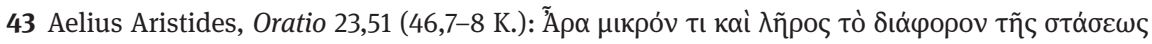

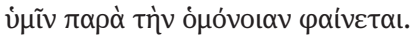


that mutual friendship and concord greatly benefit the nation, the leading and individual cites, whereas faction causes severe evil. ${ }^{44}$

Plutarch shares the opinion that discord and enmity are opposite to concord and harmony. ${ }^{45}$ Frederick E. Brenk has discussed the use of the historical example in Plutarch's Erotikos against its historical and rhetorical background. ${ }^{46}$ We thus turn to Plutarch's use of the $\pi \alpha \rho \alpha ́ \delta \varepsilon เ y \mu \alpha$ to argue in favour of concord. ${ }^{47}$

In his discourse of "Brotherly Love" (De fraterno amore) he states that concord and assistance benefit human life, not strife and discord.

And yet the illustration of such common use by brothers Nature has placed at no great distance from us; on the contrary, in the body itself she has contrived to make most of the necessary parts double and brothers and twins: hands, feet, eyes, ears, nostrils; and she has thus taught us that she has divided them in this fashion for mutual preservation and assistance, not for variance and strife. ${ }^{48}$

Plutarch asks, "what deed or favour or disposition, which children may show toward their parents, can give more pleasure than steadfast goodwill and friendship toward a brother?" ${ }^{99}$ In order to support this proposition, Plutarch mentions the positive example of Apollonis of Cyzicus, mother of King Eumenes, who always congratulated herself and gave thanks to the gods, not because of wealth or empire, but because she saw her three younger sons, Attalus and Philetaerus and Athenaeus, as members of the body-guard of her eldest, Eumenes. On the negative side, Plutarch refers to Artaxerxes, who after realising that his son Ochus had plotted against his brothers, despaired and died. ${ }^{50}$

44 Cf. Aelius Aristides, Oratio 23,52 (46,8-18 K.).

45 Cf. Plutarch, Cato Maior 21,4 (BSGRT Vitae parallelae 1,1, 316,13-20 Ziegler); Pompeius 47,3 (BSGRT Vitae parallelae 3,2, 301,27-302,2 Ziegler).

46 Brenk, “Good Exemplum” (see note 13), 206-209.

47 For the use of examples in Plutarch's “Kingship Treatises,” cf. Benjamin Fiore, The Function of Personal Example in the Socratic and Pastoral Epistles (Analecta Biblica 105; Rome: Biblical Institute Press, 1986), 67-76.

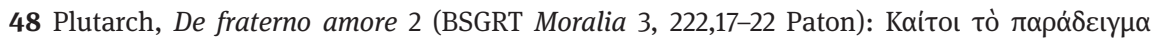

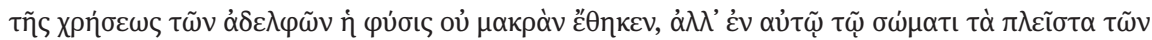

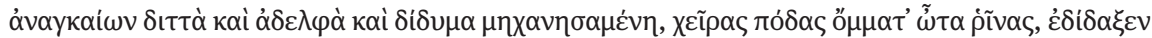

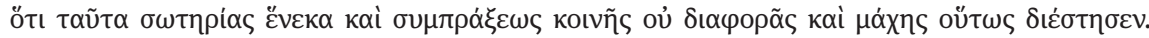
Trans. William C. Helmbold, Plutarch's Moralia 6 (Loeb Classical Library; Heinemann: London, 1939; repr. 1962), 249.

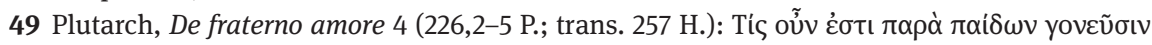

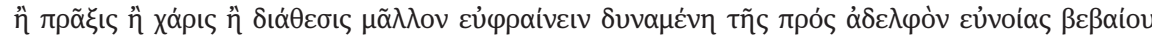

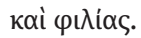

50 Cf. Plutarch, De fraterno amore 5 (226,5-227,11 P.). 
From 1 Clement 1,1 we learn that in Corinth the "shameful and detestable sedition" ${ }^{51}$ has utterly defamed $(\beta \lambda \alpha \sigma \varphi \eta \mu \varepsilon \dot{c} \omega)$ the acclaimed name of the Christians, cherished amongst all people. A few rash and self-confident persons kindled this sedition, which is utterly alien to the elect of God, to such a pitch of frenzy. For internal reasons, the congregation in Rome was slow to react, but now they do. After praising the Corinthians to "arouse their goodwill," 52 the author of 1 Clement turns the attention to the present situation in Corinth and describes the current behaviour in the congregation. Righteousness and peace are absent

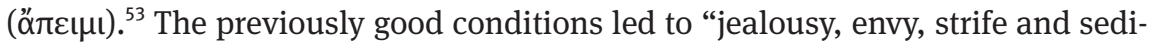
tion, persecution and disorder, war and captivity." ${ }^{54}$ This situation is the result of a rebellion of the young against those advanced in years. The author vilifies them as worthless fools without reputation, whilst the elders were honoured, renowned, wise..$^{55}$ They "took up unrighteous and ungodly envy, through which death itself entered into the world." 56

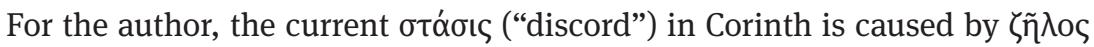
("jealousy"), which is in the course of the argument associated with $\varphi \theta$ óvos ("envy"), and हैpı ("strife"). In order to persuade his audience of his claim that unrighteous and ungodly $\zeta \tilde{n} \lambda$ os leads to death, ${ }^{57}$ the author of 1 Clement uses historical examples. The first seven examples are taken from the history of Israel as written in the Septuagint, and can be arranged according to two topics, each introduced by a citation from Scripture, followed by two we could rather classify as allusions. The beginning of the examples is clearly marked by $\delta ı \dot{\alpha} \zeta \tilde{\eta} \lambda$ os or $\zeta \tilde{\eta} \lambda$ os. ${ }^{58}$ It starts with a first example quoting Gen 4:3-8. ${ }^{59}$ In the case of Cain and $\mathrm{Abel}^{60}$ "jealousy and envy led to the murder of a brother." ${ }^{11}$ The examples two and three

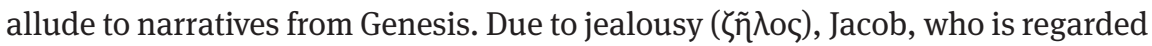
as the father of the author and the addressees (ó $\pi \alpha \tau \dot{\eta} \rho \dot{\eta} \mu \tilde{\omega} v)$, had to flee from

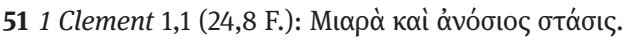

52 Bakke, “Concord and Peace” (see note 5), 208, 219, 276; cf. 1 Clement 1,2-2,8 (24,11-26,18 F.).

531 Clement 3,4 (26,25 F.).

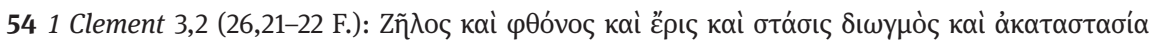

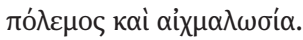

55 Cf. 1 Clement 3,3 (26,23-25 F.).

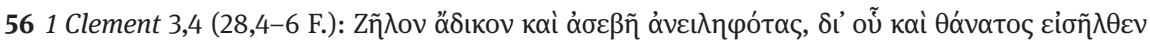

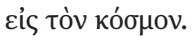

57 Cf. 1 Clement 3,4 (28,4-6 F.).

58 Cf. 1 Clement 4,8-13 (28,19.20.25.26; 30,1 F.).

59 Cf. Donald A. Hagner, The Use of the Old and New Testaments in Clement of Rome (Supplements to Novum Testamentum 34; Leiden: Brill, 1973), 38-39.

60 Cf. 1 Clement 4,1-7 (28,7-19 F.).

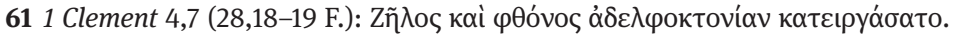


Esau, ${ }^{62}$ and Joseph was sold into slavery. ${ }^{63}$ These first three examples show that in the past jealousy and envy destroyed brotherhood, which is, albeit in a spiritual sense, one of the fundamental relations within the Christian community.

The next group of examples all focus on the devastating role jealousy had on the leadership. Example four starts with a quotation from Exod 2:14. ${ }^{64}$ Because of $\zeta \tilde{n} \lambda$ os Moses had to flee from Egypt. For examples five and six the letter then briefly alludes to Num 12-16, for seven to 1 Kings 18-26:

On account of envy, Aaron and Miriam had to make their home outside of the camp. Jealousy downed Dathan and Abiram alive to Hades, through the sedition which they excited against God's servant Moses. Because of $\zeta \tilde{\eta} \lambda$ os, David underwent the hatred not only of foreigners, but was also persecuted by Saul king of Israel. ${ }^{65}$

After these seven examples from the distant past, which were surely known to both author and addressees, the author comes to that what is the real concern by turning to an example from the generation of the addressees. First he selects an example concerning Christian leaders. "Through jealousy and envy, the greatest and most righteous pillars [Peter and Paul] have been persecuted and put to death." 66 The letter now specifically gives the causes of the martyrdom of Peter and of Paul, adding thus two extra examples on the nature of $\zeta \tilde{n} \lambda$ os. Peter suffered "because of unjust jealousy," ${ }^{\circ 7}$ Paul "because of jealousy and strife." ${ }^{68}$ After these first three examples of Peter and Paul, the letter turns to the shattering effect jealousy had on the Christian community by depicting $\zeta \tilde{\eta} \lambda$ os as reason for martyrdom. ${ }^{69}$ A multitude of male Christian martyrs "suffered because of jealousy"

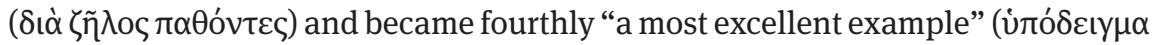

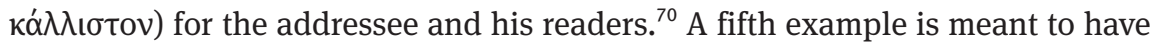
increased impact. "Because of envy" ( $\delta ı \dot{\alpha} \zeta \tilde{\eta} \lambda$ os) even women, the Danaids and Dircae, were persecuted, after they had suffered terrible and unspeakable tor-

621 Clement 4,8 (28,19-20 F.); cf. Gen 35:1.7.

631 Clement 4,9 (28,20-21 F.); cf. Gen 37.

641 Clement 4,10 (28,23-25 F.). Cf. Hagner, Use of the Old and New Testaments (see note 59), 40.

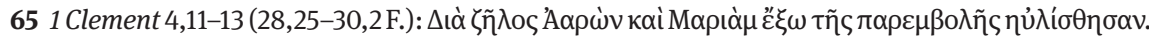

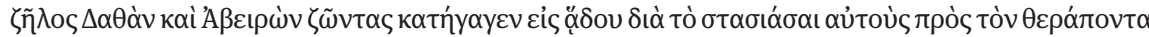

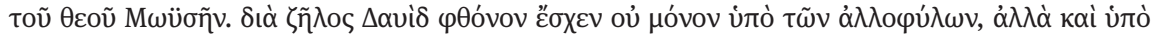

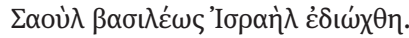

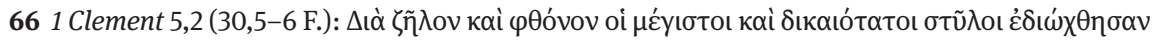

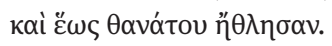

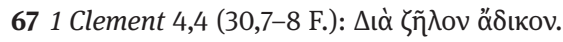

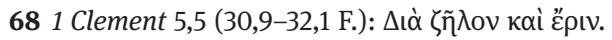

69 Cf. 1 Clement 6,1-2 (32,7-12 F.).

701 Clement 6,1 (32,9 F.). 
ments. ${ }^{71}$ In line with the rhetorical tradition the letter turns to the household and politics for examples six and seven. Zñ $\lambda$ os is the reason why wives are alienated from husbands and $\zeta \tilde{\eta} \lambda$ os and ع̌pı "have overthrown great cities and rooted up mighty nations."72

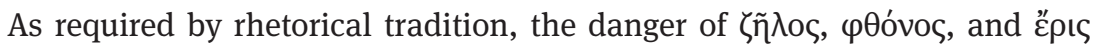
have been clearly illustrated by two rows of seven examples that are the same as the case the letter argues against. Our author thus addresses the Corinthians directly: "These things, beloved, we write to you, not merely to admonish you of your duty, but also to remind ourselves. For we are struggling in the same arena, and the same conflict is assigned to us." 73

In the next section, the author states that through his death Christ "has set the grace of repentance before the whole world." "74 Christ is not the only example that God gives the opportunity for repentance. Drawing on the historical examples of Noah and the effect of Jonah's proclamation to the Ninevites, ${ }^{75}$ the author illustrates that God "has granted a place of repentance to all who would be converted to Him." ${ }^{76}$ His call to obey God's will, to turn to his compassion and to leave "all fruitless labours, and strife, and envy, which leads to death" 77 is motivated by another set of historical examples. In the cases of Enoch and Noah, the letter alludes to the Genesis narrative. ${ }^{78}$ In the case of Abraham, ${ }^{79}$ Gen 12:1-3; 13:14-16 and 15:5-6 are quoted: ${ }^{80}$

Enoch, who, being found righteous in obedience, was translated, and death was never known to happen to him. Noah, being found faithful, preached regeneration to the world through his ministry; and the Lord saved by him the animals which, with one accord, entered into the ark. Abraham, called "the friend," was found faithful, inasmuch as he obeyed the words of God. ${ }^{81}$

71 Cf. 1 Clement 6,2 (32,9-12 F.).

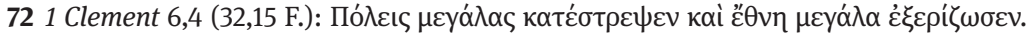

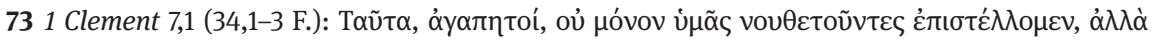

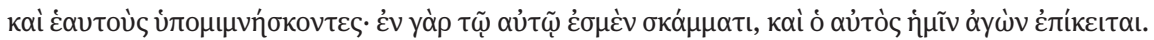

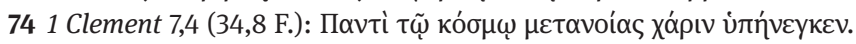

751 Clement 7,6-7 (34,11-14 F.); cf. Jonah 3.

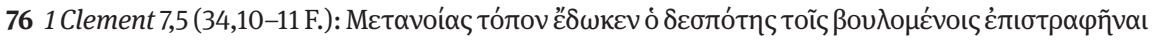
ह̇ं aủoóv.

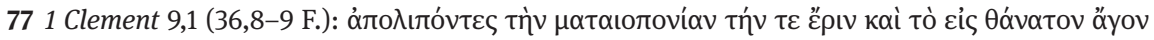
$\zeta \tilde{n} \lambda$ os.

78 Cf. 1 Clement 9,3-4 (36,10-14 F.); cf. Gen 5:24; 6-8.

79 Cf. 1 Clement 10,1-7 (36,15-38,7 F.).

80 Cf. Hagner, Use of the Old and New Testaments (see note 59), 39, 51.

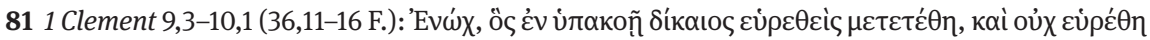

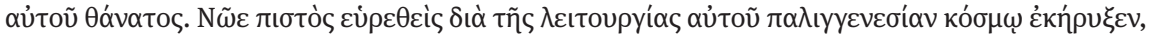


Alluding to Gen 21-22 and Josh 2, he continues that Lot was saved out of Sodom "on account of his hospitality and godliness, . . . and on account of her faith and hospitality, Rahab the harlot was saved." ${ }^{82}$ There are similar sections in the letter, but they cannot be treated in this lecture. ${ }^{83}$

In his erudite commentary on 1 Clement, Horacio E. Lona remarks, "Die Bedeutung der griechischen Bibel in 1 Clem kann kaum hoch genug angeschlagen werden." ${ }^{84}$ It is hard to disagree. But the way in which the Septuagint is cited and alluded to illustrates a different "geistiges Milieu" than the one Lona constructs. In a cultural context deeply influenced by the rhetorical tradition of the early empire, the author quotes, but Moses, Isaiah, and David's psalms instead of Homer, Hesiod and Euripides. He uses the historical example as usual in deliberative rhetoric. His examples, however, were not taken from Greek history, but from the history of Israel as told in the Greek bible. Christianity in Rome presented their appeal to biblical authority not only in the form of quotations, but also in the narration of historical examples, merging biblical history and Greek philosophical tradition in order to restore peace and concord in Corinth. By the end of the first century, a process already started by Paul, to clad biblical patterns of thought or history in Greek garb, ${ }^{85}$ was in full sway.

This does not mean, however, that the impact of the Greek bible was diminished. The author of 1 Clement knew for example the Greek notion of being delivered for someone, with which Christianity initially gave meaning to the death of Christ. ${ }^{86}$ Taking up a line of interpretation mooted by 1 Pet, ${ }^{87}$ the author

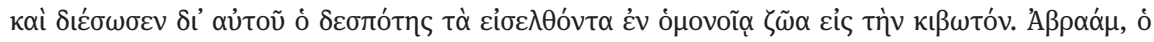

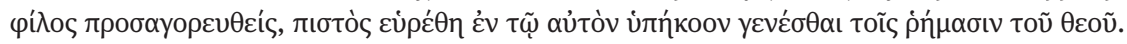

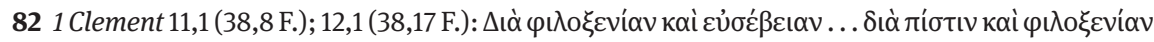

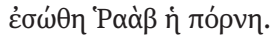

83 Cf. e.g. 1 Clement 17,1-18,15 (46,3-48,14 F.); 43,1-44,6 (78,9-80,18 F.).

84 Lona, Clemensbrief (see note 4), 42.

85 Cf. Cilliers Breytenbach, “'Charis' and 'Eleos' in Paul's Letter to the Romans,” in idem, Grace, Reconciliation Concord: The Death of Christ in Graeco-Roman Metaphors (Supplements to Novum Testamentum 135; Leiden: Brill, 2010), 207-238.

86 Cf. 1 Clement 55,1-2 (92,7-13 F.); cf. also Christina Eschner, Gestorben und hingegeben "für" die Sünder: Die griechische Konzeption des Unheil abwendenden Sterbens und deren paulinische Aufnahme für die Deutung des Todes Jesu Christi 1: Auslegung der paulinischen Formulierungen (Wissenschaftliche Monographien zum Alten und Neuen Testament 122; Neukirchen-Vluyn: Neukirchener, 2010), 16-24.

87 Cf. Cilliers Breytenbach, “ ‘Christus litt euretwegen’: Zur Rezeption von Jesaja ${ }^{\mathrm{LXX}} 53$ und anderen frühjüdischen Traditionen im 1. Petrusbrief,” in idem, Grace, Reconciliation, Concord: The Death of Christ in Graeco-Roman Metaphors (Supplements to Novum Testamentum 135; Leiden: Brill, 2010), 259-277. 
of 1 Clement inscribes this notion into the Greek text of Isa 53:6 to interpret the death of Christ in 16,7 against the backdrop of biblical tradition. But to study this should be reserved for another occasion. ${ }^{88}$

88 I am indebted to Geeske Brinkmann and Matthias Müller for checking the references and editing the manuscript. 